\title{
表面改質材の疲労強度評価とその事例
}

\author{
中谷 正憲 ${ }^{a}$, 高田 知樹 ${ }^{a}$, 齋藤 竜司 ${ }^{b}$, 橋爪 佳 ${ }^{b}$, 村田 俊也 ${ }^{b}$ \\ a(株)神戸工業試験場 ( ⿳ 675-0155 兵庫県加古郡播磨町新島 47-13) \\ b 奥野製薬工業(株) ( ⿳ 5 538-0044 大阪府大阪市鶴見区放出東 1-10-25)
}

\section{Fatigue Strength Evaluation of Surface Modified Materials and Some Examples}

\section{Masanori NAKATANI ${ }^{\mathrm{a}}$, Tomoki TAKATA ${ }^{\mathrm{a}}$, Ryuji SAITO ${ }^{\mathrm{b}}$, Kei HASHIZUME ${ }^{\mathrm{b}}$ and Toshiya MURATA $^{\mathrm{b}}$}

${ }^{a}$ Kobe Material Testing Laboratory Co., Ltd. (47-13 Niijima, Harima Town, Kako-gun, Hyogo 675-0155)

${ }^{\mathrm{b}}$ Okuno Chemical Industries Co., Ltd. (1-10-25 Hanaten-Higashi, Tsurumi-ku, Osaka-shi, Osaka 538-0044)

Keywords : Fatigue Test, Ceramic Coating, Electroless Plating, Acoustic Emission

\section{1. はじめに}

金属材料は，航空機や自動車，インフラ設備などの機械 · 構造物において構造材料として広く使用されている。引張や 圧縮, 曲げなどの力学的負荷だけでなく, 腐食性あるいは高 温の環境に曝される場合や, 部材間の接触による摩擦・摩耗 を生じる場合などその使用条件は多種多様なものとなってい る。耐食性や耐摩耗性, 耐熱性などを改善・向上し, 実使用 条件での信頼性・耐久性を確保するため, 材料の変更だけで は限界があることから, めっき処理やセラミックスコーティ ングなどの硬質皮膜を表面に付与する表面改質が適用されて いる。硬質皮膜による表面改質は, 単に耐食性や耐摩耗性を 改善するだけでなく, 基材単体に比べて疲労強度も向上させ $3^{1) \sim 3)}$ 。これは, 硬質皮膜が繰返し負荷による基材表面での すべり変形を抑制するためである。その一方で, 硬質皮膜の 強度や密着性によっては疲労強度が低下するケースも多く報 告されている ${ }^{4)}$,5)。界面での割れや硬質皮膜のはく離が応力 集中部となり, 疲労き裂発生を加速させるためである。

硬質皮膜の密着性は，基材と硬質皮膜の間に生じる物理特

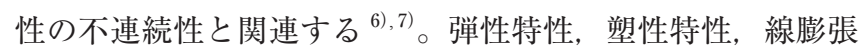
係数などが異なることによって, 同じ機械的・熱的負荷を受 けたとしても, 基材と硬質皮膜の変形量に差が生じ, 界面に 特異応力場をもたらす。それによって界面には大きな応力 (ひ ずみ)を生じ, それが許容值を超えると硬質皮膜ははく離する。 密着性を評価する方法の一つとして, スクラッチ試験が挙げ られる。表面に垂直に立てた圧子に加える荷重を増加させな がら, 圧子を水平方向に直線移動させ, 皮膜がはく離すると きの荷重から密着性を評価する手法であり, 密着性の大小関 係を順序づけることができる。仮に基材と硬質皮膜の物性が 同じで, 密着性だけが異なる場合には, 密着性の良いほうが 疲労強度は高いと考えられる。しかしながら, 表面改質材の 疲労強度は皮膜と基材の組み合わせや処理方法などに依存す るため, それを定量的に予測する手法は今のところ確立され
ていない。また，硬質皮膜の処理過程で欠陥が生成する場合 がある。欠陥が存在するような場合には，密着性に関係なく， 欠陥から早期にき裂が発生する可能性もある。

したがって, 繰返し荷重を受ける実機に表面改質を適用す る場合には，実働条件に近い環境・条件での疲労試験を実施 し，疲労強度特性に及ぼす表面改質の影響を調べるとともに， その破壊プロセスを明らかにすることが望ましい。本稿では 筆者らが実施した表面改質材の疲労試験結果を紹介するとと もに, 試験中の表面改質層の割れやはく離を検出する上で有 効と考えられるアコースティック・エミッション法について 説明する。

\section{2. セラミックスコーティング材のフレッティング疲労}

セラミックスコーティングは, 物理的気相成長法 (PVD)や 化学的気相成長法 (CVD) に大別することができる。いずれ も基材に緻密な硬質皮膜を形成することが可能であり, 工具 や金型, その他耐摩耗性や耐熱性が要求される部材に広く適 用されている。しかしながら, 使用条件や使用環境が厳しく なるにつれて, 割れやはく離が生じやすくなり, その機能を 果たさなくなることが課題となっている。これまでにその破 壞メカニズムや密着性の改善などさまざま研究が行われてき た。ここでは, 密着性改善のための方法の一つとして, PVD の 1 種であるイオンビーム支援蒸着法 (Ion Beam Assisted Deposition：IBAD） ${ }^{8)}$ を用いた傾斜機能性コーティングによ る表面改質の結果について紹介する。

IBAD 法は, 図 1 に示すように, 電子ビーム蒸着と同時に イオンビームを照射することにより硬質皮膜を形成する手法 である。イオンビーム照射により, 基材と硬質皮膜の間に互 いの成分が混合した混合層を形成し, それにより界面の整合 性が高まり, 従来の PVDによるセラミックスコーティング よりも密着性が向上する ${ }^{9)}$ とされている。しかしながら, 混 合層の厚さは数 $10 \mathrm{~nm}$ 程度であり ${ }^{10)}$, 一般的なセラミック スコーティングの膜厚が数 $\mu \mathrm{m}$ であることを考えると極めて 


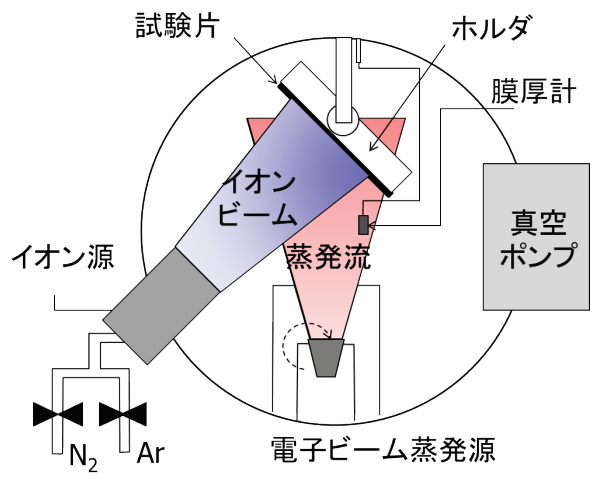

図 1 イオンビーム支援蒸着法の模式図

薄いと言える。そのため, 基材とセラミックスコーティング の物性の差が大きい場合には, 基材とセラミックスコーティ ングの界面に生じる特異応力場を十分に緩和できない。

界面近傍における材料特性の不連続性を緩和する方法とし て, 傾斜機能 ${ }^{11)}$ の概念が挙げられる。これは複合材料など 2 種類の物性の異なる材料の接合において，その間に組成の異 なる材料や中間的な物性の材料を連続的あるいは段階的に形 成することによって，元々の物性の差を滑らかに変化させる 材料設計概念であり, 高温機器や切削工具, 生体材料などに 適用されている。

図 2 は, IBAD 法により TiNを成膜したチタン合金 Ti6A1-4V ELI 材のボールオンディスク摩耗試験中の摩擦係数 の変化 ${ }^{12)}$ を示している。図中の凡例の $0.2 \mathrm{keV}, 2 \mathrm{keV}$ はイ オンビームの加速電圧を表している。TiN コーティングを施 すことによって, 磨耗試験開始後の摩擦係数は低くなってい るが，時間の経過とともに摩擦係数は増加する。これは TiN コーティングの磨耗・はく離が進み, 基材が露出しているこ とを示している。イオンビームの加速電圧を大きくすること によって, 摩擦係数が増加し始める時間が遅くなっているこ とがわかる。これは, イオンの衝突エネルギーが増加するこ とによって，基材により深くまで打ち込まれ，混合層が厚く なり，密着性が改善するためである。さらに，基材と $\mathrm{TiN}$ 層の間に傾斜機能層を形成した FG-TiN では，TiN 単層の場 合よりも摩擦係数の変化は緩やかになっている。傾斜機能層

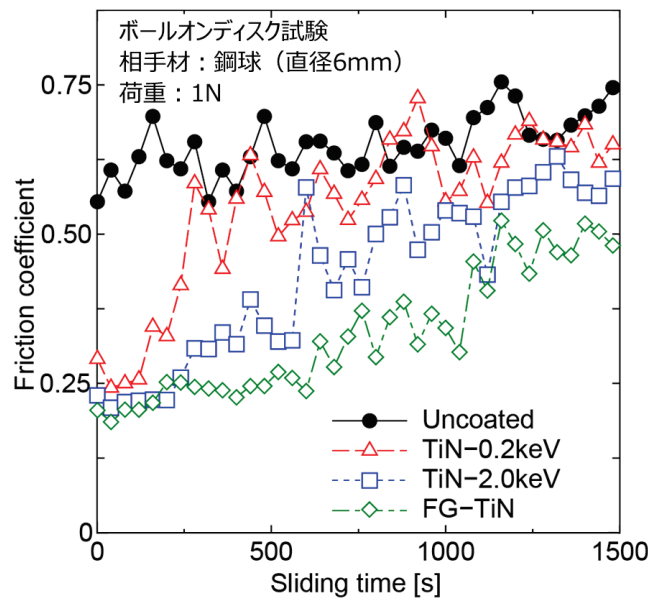

図 $2 \mathrm{TiN}$ コーティングの摩擦係数の測定結果
によって, 基材と $\mathrm{TiN}$ 層の変形特性の不連続性が緩和され, 摩耗試験中の剥離が抑制されたと考えることができる。

上述のセラミックスコーティング材に対して，自作の電磁 式疲労試験機を用いて, 両振りでの 4 点曲げ疲労試験により フレッティング度労寿命を評価した。チタン合金 Ti-6A1-4V ELI 材の平板試験片両面にコーティングを施した後, 試験片 の中央両面に接触片を接触させ，さらに治具を用いて公称接 触面圧が $25 \mathrm{MPa}$ となるように圧力をかけた状態で疲労試験 を実施している。フレッティング疲労寿命を比較した結果 ${ }^{12)}$ を図 3 に示す。単層のセラミックスコーティングを施すと, 基材のみのフレッティング疲労寿命に比べて, 約 2.5 倍に向 上した。さらに, 傾斜機能コーティング材 (FG-TiN)のフレッ ティング度労寿命は基材のそれの約 5 倍にまで向上した。傾 斜機能層が界面での機械的特性の不連続性を緩和し, 密着性 を改善したことによって，フレッティング度労寿命の大幅な 改善につながったと考えられる。

フレッティング疲労試験後の試験片表面を観察した結果 ${ }^{12)}$ を図 4 に示す。単層コーティング材では, 破面の近傍でコー ティングがはく離し，基材が露出している様子が観察された。 フレッティング疲労のように厳しい応力条件下にある場合に

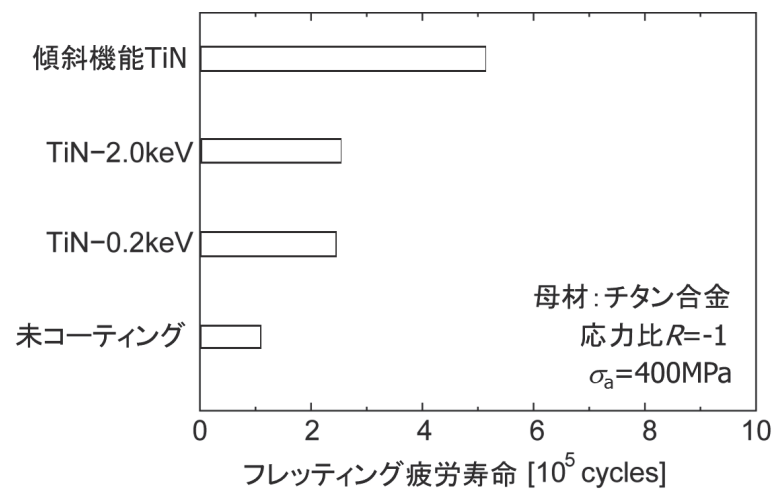

図３ＴiN コーティング材のフレッティング度労試験結果

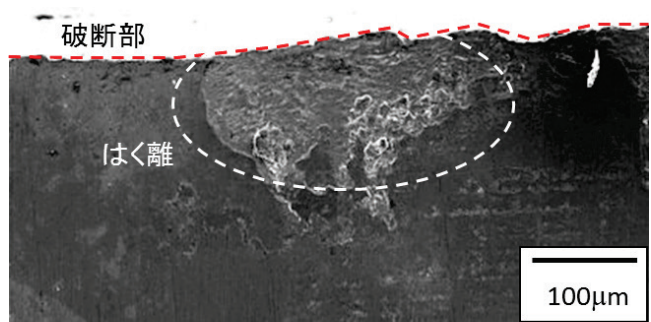

(a) $\mathrm{TiN}-2.0 \mathrm{kV}$

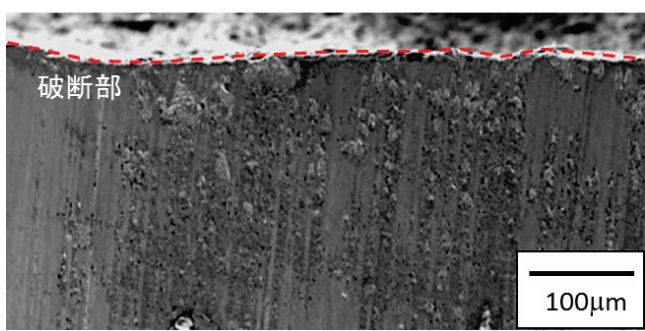

(b) FG-TiN

図４フレッティング疲労試験後の TiN コーティング材の表面状態 
は，単層のセラミックスコーティングではコーティングのは く離を生じ，それを起点として破壊が生じていた。一方で, 傾斜機能コーティング材では, 直径 $10 \mu \mathrm{m}$ 以下の小さなチッ ピング状の摩耗損傷が多数観察された。傾斜機能層の存在が 界面の特異応力場を緩和したことにより, 摩耗に起因する疲 労破壊を生じたと考えられる。したがって, 破壊の形態がコー ティングの剥離から摩耗に変化したことによってフレッティ ング疲労寿命が向上したと言える。このように，表面改質材 の疲労強度を評価する上では，単に寿命だけの評価ではなく， 破壊した試験片を観察し, その破壞プロセスを把握すること が重要である。

\section{3. めっき材の低サイクル疲労}

耐食性や耐摩耗性, 装飾性などの機能性向上のために, めっ きは様々な機械部品に用いられ, その歴史はセラミックス コーティングよりも長い。これまでに多くの研究が行われ, その品質の改良が進められてきた。しかし, 前述のセラミッ クスコーティングと同様に部品の使用環境や条件が過酷にな るとともに，その信頼性に対する要求も高まっている。

そうした中で, 無電解 Ni-P めっきは, 内燃機関に使用さ れる回転体への表面改質処理の一つとして注目されている。 無電解 Ni-P めっきは, その皮膜に含まれるリン含有率によっ て, 硬さやヤング率, めっき膜の内部応力が変化することが 知られている。ここでは, 無電解 Ni-P めっきを施したアル ミニウム合金の平面曲げによる低サイクル疲労試験結果 ${ }^{13)}$ を紹介する。

市販のアルミニウム合金 A2017 から平板試験片を製作し, 試験片の全面にNi-P めっきを施した後, シェンク式平面曲 げ疲労試験機を用いて疲労き裂発生寿命を評価した。試験は 角度制御とし， $0.2 \mathrm{~Hz}$ で正弦波による繰返し負荷を与えた。 試験初期にひずみゲージを用いて測定したひずみ範囲は $0.8 \%$ である。き裂発生は試験中の曲げモーメントが $1 \%$ 低 下した時点とした。これは, き裂長さが約 $0.5 \mathrm{~mm}$ に相当す ることを実体顕微鏡によるその場観察で事前確認している。 図 5 は, リン含有率と疲労き裂発生寿命の関係 ${ }^{13)}$ を示して いる。基材のき裂発生寿命に比べて，めっきを施してもき裂

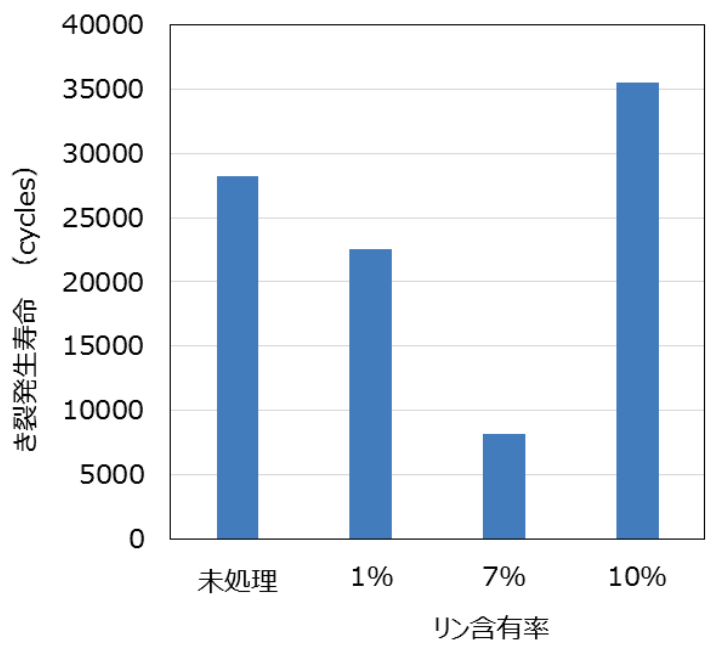

図 5 めっき材の平面曲げ疲労試験結果
発生寿命が長くなる場合と短くなる場合があることがわかる。 めっき材で比較すると，リン含有率が $7 \mathrm{wt} \%, 1 \mathrm{wt} \%$, $10 \mathrm{wt} \%$ の順にき裂発生寿命は長くなった。一般に, Ni-P めっ きはリン含有率が減少するほど, 硬さは増加し, 延性は減少 する ${ }^{14)}$ 。低サイクル疲労域では, 疲労初期から材料全体(曲 げの場合には, 表面近傍のみ) が塑性変形を伴う。したがって, 延性の低い硬質な皮膜では基材の塑性変形に追従できず，早 期に割れることで低寿命になり，逆に，リン含有率が高く， 延性の高い皮膜のほうが基材に生じる塑性変形に追従するこ とができるため長寿命になったと考えられる。今回，リン含 有率 7\% の場合，硬さや延性はリン含有率 $1 \%$ と 10\%の中間 であると考えられるが, 最も短寿命となった。無電解 Ni-P めっきの疲労においては, 繰返し負荷によって構造緩和や結 晶化が生じると報告されている ${ }^{15)}$ 。リン含有率が異なるこ とで，それらの起こりやすさが異なっている可能性もあるが, 現時点では十分に明らかになっていない。

なお，高サイクル疲労域では，リン含有率が低く，硬い皮 膜のほうが疲労強度は高いことが報告されている ${ }^{14)}$ 。高サイ クル疲労域では，マクロには弾性変形が支配的で，局所的に 繰返しに伴う微小なすべり変形が蓄積し, 疲労き裂の核となる。 そのため, 硬質な皮膜になるほど，すべり変形を抑制する効 果が高く, 疲労強度の上昇につながると考えられている。

図 6 の疲労試験中の表面観察写真に示すように, 基材では 2つの屈曲を伴ったき裂が発生・進展している。一般に，金 属材料の低サイクル疲労では, 数 $10 \mu \mathrm{m}$ のき裂が比較的早

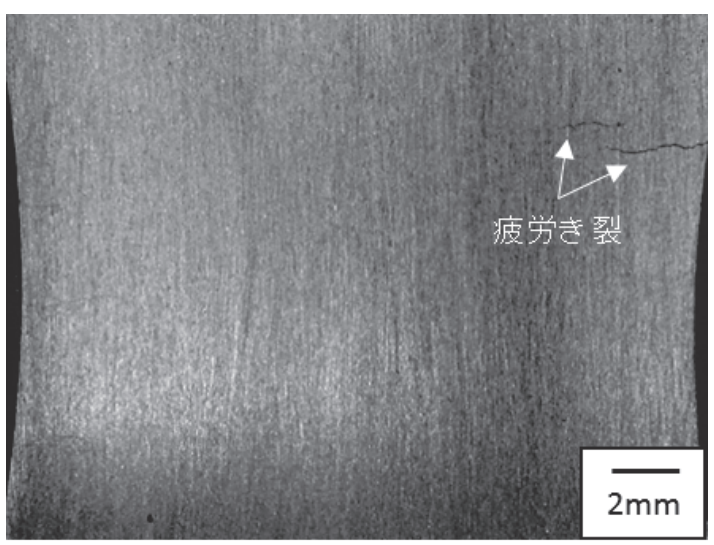

(a)母材

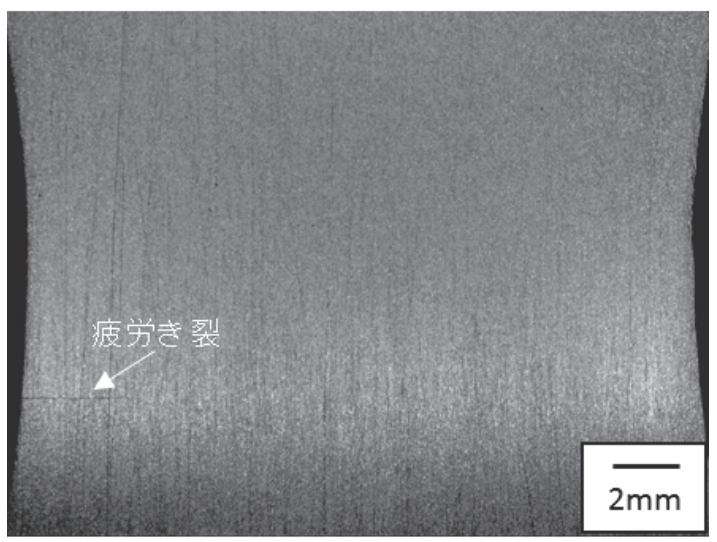

(b)施っき材(リ含有率 $10 \%)$

図 6 めっき材の疲労き裂観察例 
い段階から複数発生し, それらが成長・合体を繰り返して破 断に至る。一方，めっき材では直線的なき裂が観察されてい る。金属に硬質皮膜を施した場合の低サイクル疲労挙動に関 して，硬質皮膜の存在が基材の転位運動を拘束することでき 裂の発生を遅延させると考えられている ${ }^{16)}$ 。しかし, 前述 のように，硬質皮膜が基材の変形に追従できなくなると，硬 質皮膜は割れてしまう。皮膜自身がぜい性的であるため，そ のき裂は急速かつ直線的に拡大し，それを核として基材部の き裂の発生も加速する。

\section{4.アコースティック・エミッション法}

めつきやセラミックスコーティングなど硬質皮膜を伴う表 面改質の場合には，皮膜自身の疲労強度，とりわけ疲労き裂 発生寿命を把握しておくことが重要である。例えば，耐食性 の向上を目的としためっきを施したにもかかわらず，それが 割れてしまうと, そのき裂の中に腐食性溶液が浸透し, 基材 に到達する。そのような状況では, 基材と硬質皮膜の間でガ ルバニック腐食を誘起し, 基材単体よりも腐食を加速させて しまう可能性がある ${ }^{17)}$ 。

前節で紹介したように，疲労試験中にその場で実体顕微鏡 により連続観察する方法はある程度大きくなったき裂の観察 には有効であり，めっきの違いによって，あるき裂長さまで 成長するまでの寿命を比較する分には問題はない。しかし, 視認できる長さは $\mathrm{mm}$ オーダであり，上記のような薄い皮 膜の場合にはすでに基材まで貫通していると考えられる。そ のため, 厳密な意味での皮膜自身のき裂発生寿命ではないた め, 注意が必要である。実験室レベルでのき裂観察の手法と しては，他にレプリカ法がよく用いられている。これは，溶 剤に浸したアセチルセルロースフィルムを試験片に貼り付け， 試験体の凹凸を転写し，そのフィルムを観察する手法であり， 電子顕微鏡などを使用すれば微小なき裂も観察することがで きる。観察のためには試験を中断する必要があり，連続的な 観察には時間と手間を要する。

このような表面観察に対して, 材料内部に生じる動的な変 化を解析する手法として，アコースティック・エミッション (AE : Acoustic emission) 法 ${ }^{18)}$ がある。 $\mathrm{AE}$ 法は材料の変形や き裂発生に伴う弾性波を検出することで，変形やき裂発生の タイミングを調べる非破壊検査手法である。ここでは, $\mathrm{AE}$ 法について紹介する。

\section{4. $1 \mathrm{AE}$ 法とは}

アコースティック・エミッション, $\mathrm{AE}$ とは材料の変形時 やき裂の発生，伸展時に材料内部のひずみエネルギーが弾性 波として放出される現象のことを指す。弾性波とは振動，つ まり音なので，木材を折るときに「ボキッ」という音がする ことや錫を変形させるときに音が発生する錫鳴り現象は可聴 域の $\mathrm{AE}$ の一種である。 $\mathrm{AE}$ によって発生した弾性波を $\mathrm{AE}$ 波と呼び， $\mathrm{AE}$ 波は微細な振動として材料内部を伝播する。 図 7 に示すように，圧電素子などから構成される $\mathrm{AE}$ センサ を材料表面に取り付け，伝播してきた $\mathrm{AE}$ 波を検出する検査 手法を $\mathrm{AE}$ 法と呼ぶ。 $\mathrm{AE}$ センサによって電気的な信号に変 換された $\mathrm{AE}$ 波を解析し, $\mathrm{AE}$ 波の発生源について調べるこ とも $\mathrm{AE}$ 法の目的である。これと似たような現象が，より大

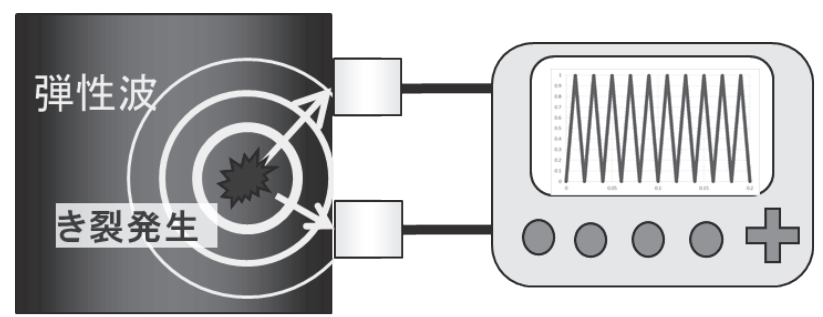

\section{$A E$ 計測装置}

図 7 アコースティック・エミッション法の測定概略

きな規模で発生したものが地震である。地震では地下深くに おいて発生した地殼の変形などによって, 地殼などに溜まっ ていた巨大なひずみエネルギーが解放され地震波として伝播 する。地震波は各地の地震計によって計測され, エネルギー が十分に大きければ地表に居る我々にも知覚することができ る。この場合, 地殼が材料, 地震波が $\mathrm{AE}$ 波, 地震計や我々 自身が AE センサにそれぞれ対応する。

$\mathrm{AE}$ 波は数十 $\mathrm{kHz}$ ～数 $\mathrm{MHz}$ の高い周波数成分を持ってお り，このような高周波域の振動を利用している点で $\mathrm{AE}$ 法は 超音波探傷検査と通ずる部分がある。超音波探傷検査は能動 的に超音波を発生させ，材料中の欠陥などを調べる検査法で あるのに対し, AE 法は材料中で発生した超音波を受動的に 捉える検査法である点が異なる。 $\mathrm{AE}$ 法は受動的な検査法で あるため, 検査対象の製品や構造物に取り付ける必要がある ものは $\mathrm{AE}$ 波を検出する $\mathrm{AE}$ センだけであり, 検査対象に 大掛かりな設備を設置する必要がない。そのほかにも $\mathrm{AE}$ 法 の利点としては，以下のような点が挙げられる。

・AE 法は材料から発せられる $\mathrm{AE}$ 波を検出する手法であ るので, 非破壞的に材料内部で生じている変化を検出す る事ができる。

・ AE センサは小型であることから，既存の設備を大きく 改変することなく, また, 検査時に設備を停止すること なく稼働状態のままで連続的に $\mathrm{AE}$ 計測および解析によ る診断などを行うことができる。

・AE 波が到達する範囲を検査範囲とするので, 1 つのセ ンサで広範囲のモニタリングが可能である。

図 8 に示すように， $\mathrm{AE}$ 波は大きく 2 種類に分けることが でき, 連続型は塑性変形など比較的小さいエネルギーで連続 して生じるのに対して, 突発型はき裂の発生や不連続な進展 など大きなエネルギーを伴う場合に見られる。したがって， 計測中の $\mathrm{AE}$ 波を解析することで，材料内にどのような変化 が生じているかを把握することができる。また，時刻歴から き裂発生の夕イミングも調べることができる。さらに，複数 の $\mathrm{AE}$ センサ用いることで，それぞれの $\mathrm{AE}$ センサに $\mathrm{AE}$ 波が到達した時間の差異を調べることで, $\mathrm{AE}$ 波の発生源の 位置を推測することができる。

\section{4. $2 \mathrm{AE}$ 法の適用事例}

$\mathrm{AE}$ 法は弾性波を発生させる現象に対応しており，圧力容 器の欠陥・腐食診断 ${ }^{19)}$, 20) や工具や軸受など摩耗・劣化のモ ニタリング ${ }^{21,22)}$, 機械・構造物の疲労劣化診断 ${ }^{23)}$ など様々 な分野で活用されている。 


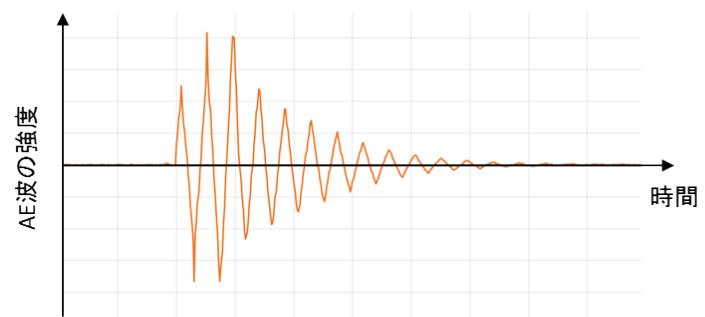

(a) 突発型 $A E$

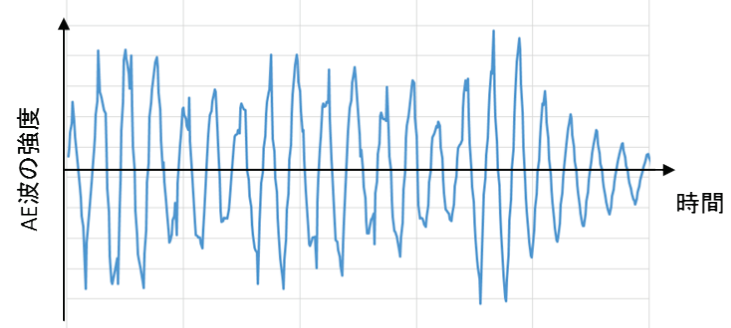

(b) 連続型AE

図８アコースティック・エミッション法により測定される $\mathrm{AE}$ 波の例

表面改質材のき裂検出に $\mathrm{AE}$ 法を利用した研究として, 耐 熱用の遮熱コーティングやセラミックスコーティングにおけ る熱疲労 ${ }^{24)}$ や熱衝撃 ${ }^{25}$ に対して適用した事例が複数報告さ れている。また，密着性の評価に使用されるスクラッチ試験 においても，AE 計測を同時に行うことで，試験中の割れや はく離を正確に検出することができるようになっている ${ }^{26)}$ 。

\section{5.おわりに}

沉用の金属材料であれば，これまでに多くの疲労試験が行 われており，そのデータが多く存在し，データベースとして も公開されている。また，引張強度や硬さなど機械的特性か らある程度疲労強度を推定することも可能である。一方，七 ラミックスコーティングやめっきなどの表面処理を施すと, 多くの場合疲労強度は向上する。しかし, その疲労強度を予 測・推定する術は現在のところ確立されていない。表面処理 を専門とするメーカでさえも十分なデー夕を保持していると は言えない。したがって，表面改質を実機に適用する際には， 疲労試験を実施し, 疲労強度に問題がないか確認することが 望ましい。

表面処理の品質は必ずしも均一ではなく，欠陌が少なから ず存在する。中でも基材が露出しているピンホール欠陥は耐 食性を劣化させるだけでなく，その欠陥を起点とした疲労破 壊を誘発する可能性がある。テストピースを用いた疲労試験 では，試験の数が限られることから，いわゆる S-N 線図で整 理しただけでは，問題が顕在化しないケースがある。特に， 耐久試験では，その対象物が壊れなかったということが分か るだけであり, 得られる情報は少ない。疲労試験では, “壊す” ことではじめて，それがどこから，どのような過程を経て破 壊に至ったかを知ることができる。疲労試験を行い，得られ る寿命デー夕も重要ではあるが，それ以上に，き裂がいう，
どこから発生し，どのように進展しているかを調べることに よって，表面改質を施した部材の品質・信頼性を保証し，実 働中の不具合を回避することができると考える。

\section{謝辞}

本稿で紹介した研究の一部は, JSPS 科研費 JP25820012 の助成を受けたものである。

(Received March 15, 2019)

\section{文献}

1 ）泉 久司, 砂田久吉, 近藤幸夫, 山崎 徹 ; 日本金属学会誌, 44, (7), 829 (1980).

2 ）田上道弘, 麻生節夫, 後藤正治, 小池一男 ; 軽金属, 43, (5), 281 (1993)

3 ) 塩沢和章, 大島誠司 ; 材料, 39, (442) 958 (1990).

4 ) K. Shiozawa, S. Nishino, K. Handa ; JSME Int. J., 35, (3), 347 (1992).

5 ) M. P. Nascimento, R. C. Souza, W. L. Pigatin, H. J. C. Voorwald ; Int. J. Fatigue, 23, 607 (2001).

6 ）岩村栄治; 表面技術, 58, (5), 260 (2007).

7 ) 神田一隆, 嶋田安広, 蓮井俊介; 福井工業大学研究紀要, 39, 115 (2009).

8 ) J. K. Hirvonen ; Mat. Sci. Rep., 6, 215 (1991).

9 ) W. Ensinger, A. Schröer, G. X. Wolf ; Nuc. Instr. and Methods in Phy. Res. B, 80/81, 445 (1993).

10) A. Perez, E. Abonneau, G. Fuchs, M. Treilleux, C. J. McHargue, D. L. Joslin ; Nuc. Instr. Methods in Phy. Res. B, 65, 129 (1992).

11) M. Koizumi, M. Niino ; MRS Bulletin, 20, 19 (1995).

12）中谷正憲, 清水翔太, 原田泰典, 内田 仁 ; 日本機械学会論文集, 81, (824), 14-00590 (2015).

13）齋藤竜司, 橋爪 佳, 村田俊也 ; 表面技術協会第138回講演大会要 旨集, 13D-08 (2018).

14）泉 久司, 砂田久吉, 近藤幸夫 ; 材料, 26, (281), 164 (1977).

15）山崎 徹, 泉久 司, 砂田久吉, 近藤幸夫 ; 日本金属学会誌, 45 , (7), 704 (1981).

16）塩沢和章, 韓 玲 ; 日本機械学会論文集A編, 59, (559), 733 (1993)

17）塩沢和章, 友坂敏信, 韓 玲, 本林 功; 日本機械学会論文集 $\mathrm{A}$ 編, 60, (571), 626 (1994).

18）長谷亜蘭; 精密工学会誌, 78, (10), 856 (2011).

19）湯山茂徳, 山田 實, 関根和喜; 圧力技術, 40, (4) 176 (2002).

20）前田 穣, 橋本弥古武, 橋脇正浩, 関根和喜, 山田 實; 圧力技術, 51, (5) 269 (2013)

21）迫 孝司, 吉江 修; 電気学会論文誌D, 132, (4) 501 (2012).

22）岩田一明, 森脇俊道, 橋本英文, 柴坂敏郎; 精密機械, 46, (7) 875 (1980).

23）湯山茂徳, 李 正旺, 友清 剛, 吉沢 勝, 魚本健人 ; 土木学会論 文集, 627, 251 (1999).

24）山崎泰広，吉田敏彦，深沼博隆，大野直行 ; 材料, 58, (2), 168 (2009)

25）橋田俊之, 石川 幹, 戸邊 務, 高橋秀明; 日本機械学会論文集A 編, 58, (545), 15 (1992)

26）熊谷 泰, 西口 晃; 金属表面技術, 37，(9),575（1986）。 